\title{
Crustal Structure and Tectonic Setting over the Panafrican Domain in Loum-Minta Area (Centre-East Cameroon) from Aeromagnetic Analysis
}

\author{
Jean Aimé Mono1,2*, Marcelin Bikoro Bi-Alou ${ }^{3}$, Arsene Meying4, Theophile Ndougsa-Mbarga',5, \\ Stéphane Patrick Assembe ${ }^{6}$, Crépin Timoléon Kofané ${ }^{1}$
}

\author{
${ }^{1}$ Postgraduate School of Sciences, Technologies \& Geosciences, University of Yaoundé I, Yaoundé, Cameroon \\ ${ }^{2}$ Basical Sciences Teaching Department of Advanced Technical Teacher Training School, University of Douala, Douala, Cameroon \\ ${ }^{3}$ Department of Earth Sciences, Faculty of Science, University of Maroua, Maroua, Cameroon \\ ${ }^{4}$ School of Geology and Mining Engineering, University of Ngaoundere, Ngaoundere, Cameroon \\ ${ }^{5}$ Department of Physics, Advanced Teacher's Training College, University of Yaoundé I, Yaoundé, Cameroon \\ ${ }^{6}$ Faculty of Science, University of Bamenda, Bambili, Cameroon \\ Email: *monojeanaime@yahoo.fr
}

\begin{abstract}
How to cite this paper: Mono, J. A., Bi-Alou, M. B., Meying, A., Ndougsa-Mbarga, T., Assembe, S. P., \& Kofané, C. T. (2019). Crustal Structure and Tectonic Setting over the Panafrican Domain in Loum-Minta Area (Centre-East Cameroon) from Aeromagnetic Analysis. Journal of Geoscience and Environment Protection, 7, 61-81. https://doi.org/10.4236/gep.2019.74005
\end{abstract}

Received: February 27, 2019

Accepted: April 15, 2019

Published: April 18, 2019

Copyright (อ 2019 by author(s) and Scientific Research Publishing Inc. This work is licensed under the Creative Commons Attribution International License (CC BY 4.0).

http://creativecommons.org/licenses/by/4.0/

\section{(c) (i) Open Access}

\begin{abstract}
The present work aims to determine the geological structure, to highlight and to determine the characteristics of the fault system responsible for the current structure of the study area through the interpretation of available aeromagnetic data. Total magnetic intensity anomaly (TMI) was critically interpreted using several analysis techniques including Reduction to Equator (RTE), First Vertical Derivative, upward continuation, spectral analysis and $2 \mathrm{D}^{3 / 4}$ modelling. All results obtained from the interpretation process were combined together to draw an interpretative geological map of the area and allow the general view of the surface and sub-surface structures. The interpretative geological map reveals that the geological formations of the studied area appear to be intensely fractured by an E-W, ENE-WSW and NE-SW main orientation fault system. The lineaments identified in the area study could be linked to the Pan-African orogeny and seem to correspond to deep-seated basement structures, which are referred to the tectonic boundary between Congo Craton and the Pan-African orogeny belt. According to spectral analysis results, the depths of the sources of superficial and deep magnetic anomalies are $2500 \mathrm{~m}$ and $12,000 \mathrm{~m}$ respectively. The $2 \mathrm{D}^{3 / 4}$ modelling of one magnetic profile plotted on the reduced residual map at the equator was performed to approximate the geometry and depth of the sources of magnetic anomalies, the model suggests the intrusion of a large body of high susceptibility during the continental collision. The results of this study can be used to
\end{abstract}


better understand deep-seated basement structures and to support decisions with regard to the development of industrial areas, as well as of hydrogeological and/or mining investigations to be undertaken in the study area.

\section{Keywords}

Aeromagnetic, Upward Continuation, Spectral Analysis, Modelling 2D $\mathrm{D}^{3 / 4}$

\section{Introduction}

Precambrian crustal evolution in Central Africa ranges from Archean to Neoproterozoic. In the Archean, the witnesses of the Liberian orogeny meet in the Congo Craton are represented in Cameroon by the Ntem unit. In the Paleoproterozoic, the Eburnean orogeny corresponds to the West Belt of Central Africa (Feybesse et al., 1998) represented in Cameroon by the Nyong and Ayina units. This crustal evolution ends in the Neoproterozoic with the Pan-African Orogeny at the origin of the Central African Mobile Zone (CAMZ) or North-Equatorial Pan-African Chain extending from the northern edge of the Congo craton to the Eastern Nigeria, including Cameroon. The CAMZ is the subject of numerous studies in Cameroon through different methods of geological and geophysical investigations. The objectives of these different studies are, on the one hand, to determine the characteristics of the geological structures, the tectonic evolution of the different geological units and on the other hand to highlight physical indices and the structural features favorable to the presence of deposits exploitable (ores, hydrocarbons, groundwater, etc.).

Gravity and audio-magnetotelluric studies by Tadjou et al., 2009; Shandini et al., 2010; Meying et al., 2009 \& 2013; Basseka et al., 2011; Ndougsa et al., 2011 revealed that, on one hand, the Northern Congo Craton Boundary was characterized by a network of faults which traverse the region of study and on the other hand, the major structures of the area had E-W, WSW-ENE, NE-SW and NNE-SSW orientations. Nevertheless, all these studies do not give sufficient information on the characteristic of structures of the subsoil of the studied area. The present study therefore aims to further deepen the knowledge of lineaments through their spatial mapping and their characteristic in order to obtain a better interpretative structural map of the study area. The resolution of such problems is made possible through the use of potential methods such as the aeromagnetic method. This method takes advantage of the correlation between the variations of the magnetic field and the susceptibility of the rocks of the subsoil. It can be used to identify basement structures. Indeed, the qualitative and quantitative interpretations of the anomalies of the magnetic field make it possible to evaluate the distribution of the geological structures of the crust.

\section{Geologic and Tectonic Setting of Study Area}

The study area is located northeast of Yaoundé (Cameroon), in the Mobile Zone 
of Central Africa, at the northern edge of the Craton of Congo. It is bounded by the meridians $12^{\circ} 00^{\prime}$ and $13^{\circ} 00^{\prime}$ east longitude and the parallels $4^{\circ} 00^{\prime}$ and $5^{\circ} 00^{\prime}$ north latitude (Figure 1). Most of the outcrops of Cameroon are constituted by units set up during the pan-African orogeny. These units form a vast $\mathrm{E}-\mathrm{W}$ belt, known from Sudan to the Gulf of Guinea and Brazil. This mobile zone belongs to the Panafrican chain of Oubanguids or Mobile Zone of Central Africa which borders the Congo craton to the North (Poidevin, 1983). Its structure is that of a chain of collision between the Congo craton in the South and a cratonic area north of Adamaoua-North RCA. It overthrust the craton to the south, the latter extending in depth over a hundred kilometres to the north, under the Yaoundé. The Pan-African chain is crossed by two large NE-SW dextral mylonitic shear zones which are the Sanaga Fault and the Cameroon Center Shear zone, which cross the country from South-West to North-East. The formations involved are metavolcano-sediments. Their age is generally attributed to the middle to lower Proterozoic, Birrimian by analogy to Francevillien of Gabon for some authors. On the other hand, the metamorphism and overthrust of the Yaounde Group as well as the granitizations are clearly Panafrican (550 - 670 Ma).

This chain includes two major entities:
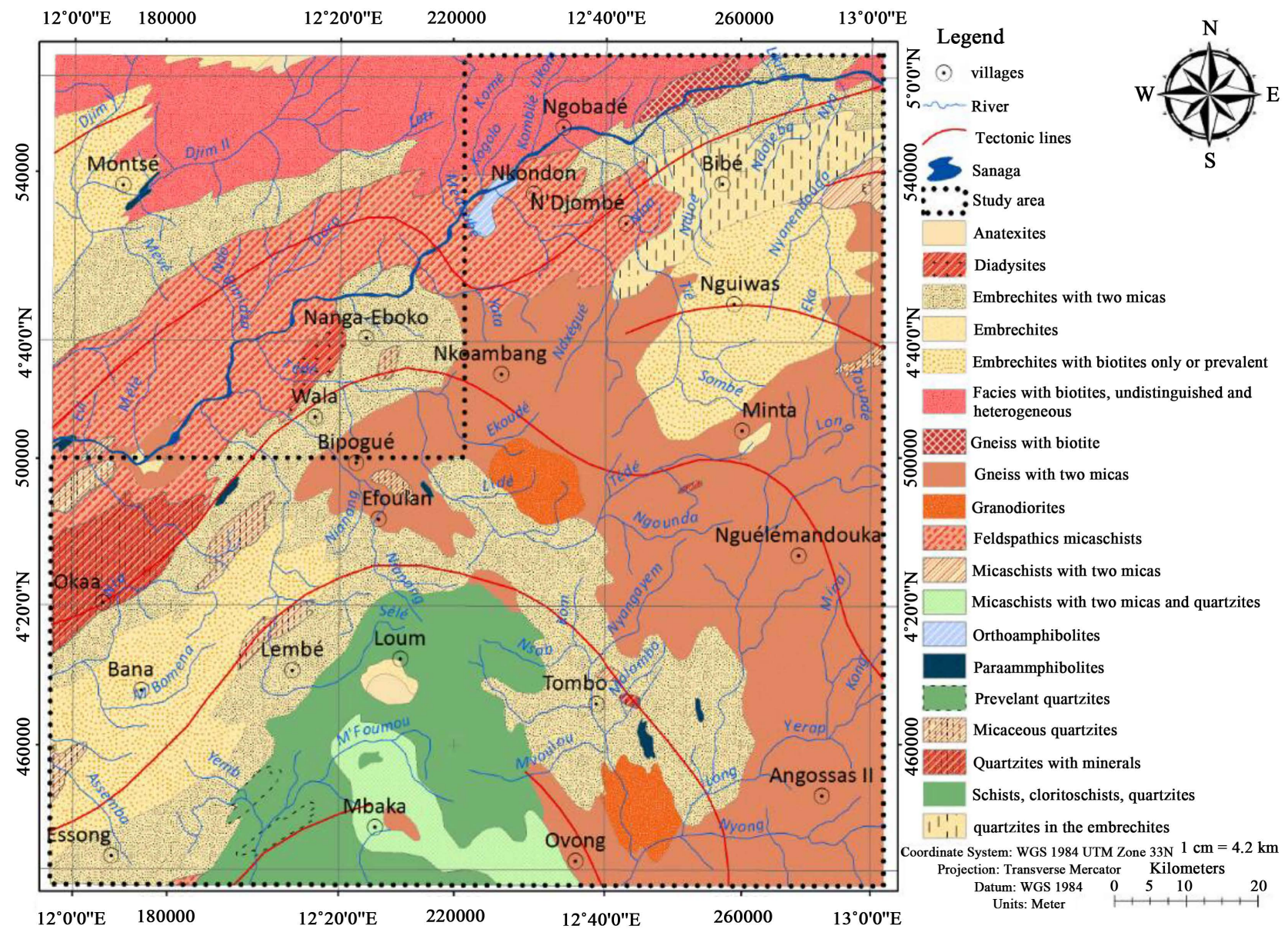

Figure 1. Geological map of the study area (Gazel, 1954). 
- crystallophyllian and migmatitic formations of parserial origin, initially quartzo-pelitic to volcano-sedimentary, formerly called "intermediate series", grouped by Maurizot et al. (1986) under the name of "Yaoundé Group" to underline its remarkable homogeneity, or series of Ayos, Mbalmayo-Bengbis, Yokadouma, Lom, Poli and Yaounde by Vicat (1998). They are affected by metamorphic conditions ranging from green shale to granulite;

- granitoids which are either granites of anatexis or syn and postectonic granites, the most frequent of which are calc-alkaline in nature. These rocks occupy mainly the central part of the Chain.

The tectonic evolution of the area was affected by the Pan-African tectonothermal event which is characterized by a polyphase deformation with the stages $\mathrm{D}_{1}-\mathrm{D}_{4}$ as reported by (Mono et al., 2018a; Mvondo et al., 2003 \& 2007; Kwekam et al., 2010; Owona et al., 2008). $\mathrm{D}_{1}$ predated emplacement of calc-alkaline dioritic bodies and caused the formation of nappes that resulted in high-pressure granulite metamorphism of soft sediments. A strong overprinting of these nappes during $\mathrm{D}_{2}$ symmetric extension, probably associated with large-scale foliation socking and (or) gneissic doming and intense magmatic underplating, gave rise to regional flat-lying fabrics. The latter were further buckled by $\mathrm{D}_{3}$ and $\mathrm{D}_{4}$ folding phases defining a vertical constriction occurring with a major east-west to NW-SE shortening direction. The corresponding $\mathrm{F}_{3}$ and $\mathrm{F}_{4}$ folds trend north-south to NE-SW and east-west to NW-SE, respectively, and represent the main regional strain patterns. Based on the east-west to NW-SE maximum shortening orientation indicated by $\mathrm{F}_{3}$ folds, it is proposed that the nappe-stacking phase $\mathrm{D}_{1}$ occurred in the same direction.

\section{Previous Geophysical Studies}

The most relevant geophysical studies were recently carried out in Centre-east Cameroon to infer the subsurface basement depth and the contact locations affecting the area (Mono et al., 2018a; 2018b). According to Mono et al. (2018a), the depth magnetic basement ranges from 150 to $3000 \mathrm{~m}$ and the structures have E-W, WSW-ENE, NE-SW and NW-SE trends. A multiscale analysis based on the coupling of the horizontal gradient method with that of the upward continuation and Euler deconvolution have been applied to aeromagnetic data to highlight faults from shallow to deep depths, as well as their strikes and dips (Mono et al., 2018b). The upward continuation was applied to the TMI-RTE map at various altitudes $(1000 \mathrm{~m}, 2000 \mathrm{~m}, 3000 \mathrm{~m}$ above measurement surface), followed by the calculation of the horizontal gradient maxima for each level. All maxima were plotted as points with different colors depending on the continuation level (Figure 2). The overlay of maxima presented in Figure 2 underlines the various contacts present in the area and indicates their dips. The predominant directions are E-W, ENE-WEW, NE-SW, and secondary directions NE-SW, NW-SE and WNW-ESE. According to the Euler deconvolution method, source depth of anomalies ranges from 100 to $2500 \mathrm{~m}$ (Figure 3) (Mono et al., 2018a; 2018b). 


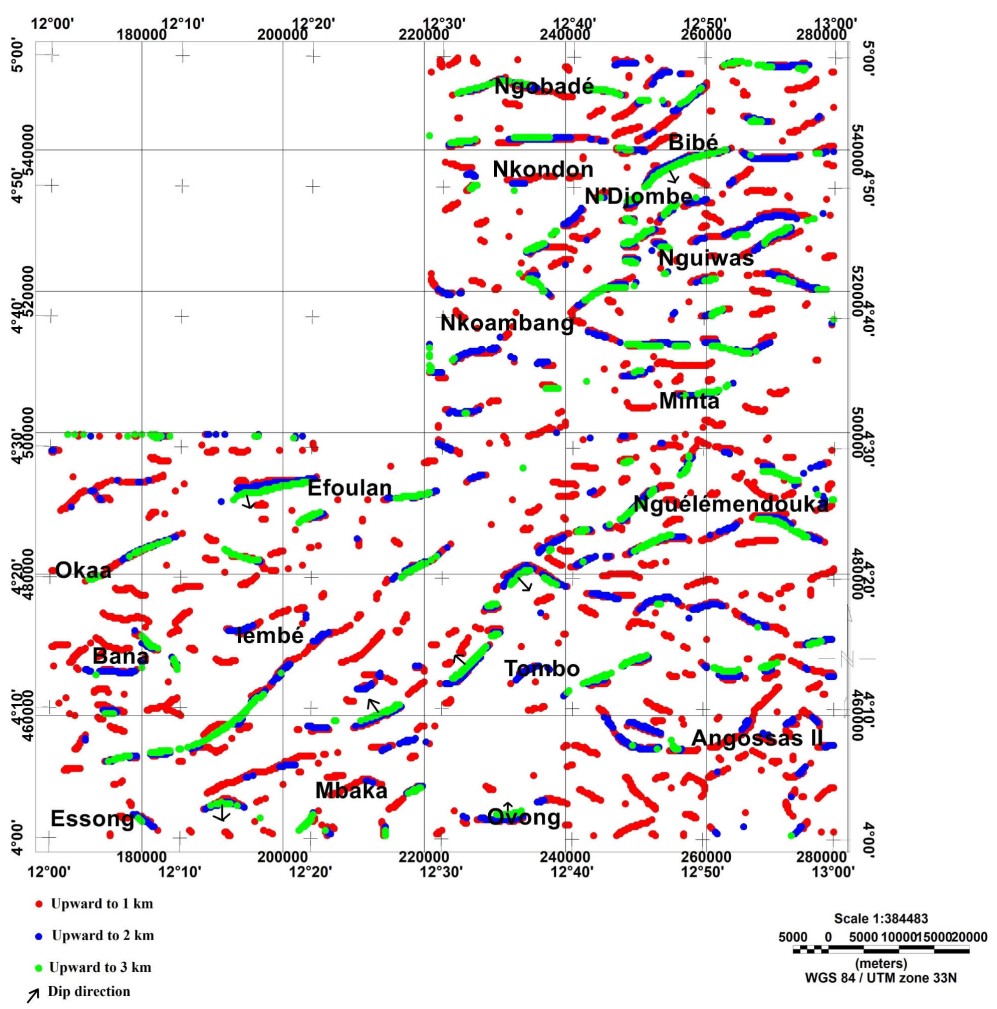

Figure 2. Superposition of maxima of horizontal gradient of TMI-RTE upward continued to $1 \mathrm{~km}, 2 \mathrm{~km}$ and $3 \mathrm{~km}$ (Mono et al., 2018b).

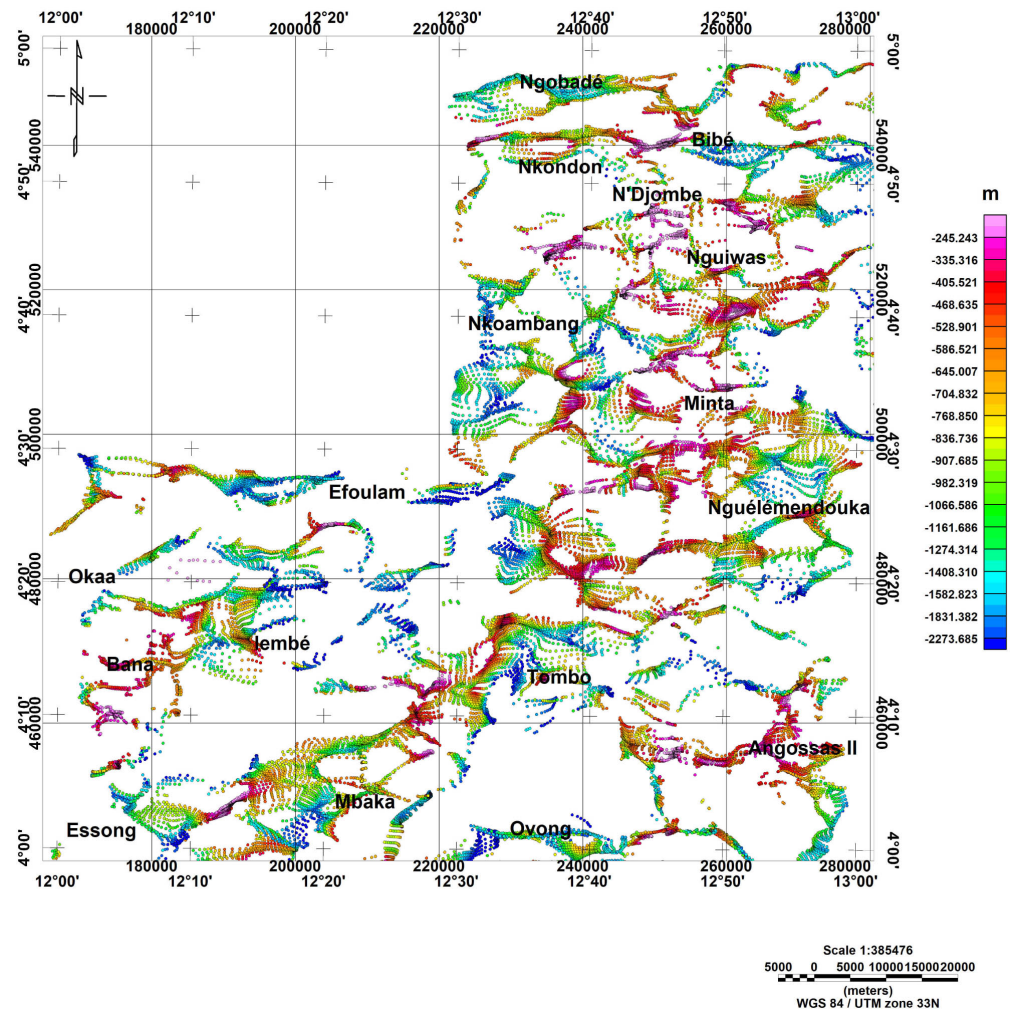

Figure 3. Euler's solution of TMI residual $\mathrm{N}=1, \mathrm{~T}=15 \%, \mathrm{~W}=10 \mathrm{~km} \times 10 \mathrm{~km}$ (Mono et al., 2018a). 


\section{Materials and Methods}

\subsection{Aeromagnetic Data}

The key component of this study involved image enhancement of existing aeromagnetic datasets acquired by the company SURVAIR (contractor) for the CIDA (client) in 1970. Aeromagnetic surveys were flown with a flight height of $235 \mathrm{~m}$ and a nominal flight line spacing of $750 \mathrm{~m}$ in direction $\mathrm{N}^{\circ} 135$. After correction of the measurements for the temporal variations of the magnetic field, the total magnetic intensity (TMI) anomaly was deduced by subtracting the theoretical geomagnetic field or IGRF (International Geomagnetic Reference Field) at each station. The TMI anomaly data were then upward continued to a height of a mean clearance of $1 \mathrm{~km}$ before they were merged into a unified digital grid, which has a cell size of 0.01 degree (i.e. $1.1 \mathrm{~km}$ ). The reduction to the Equator method is applied. In this case, the magnetic field and magnetization will be horizontal as most of the magnetized sources. The Geosoft package software V 8.4 was used to reduce the field to equator (RTE) transformation of an anomaly in the Fourier domain. The inclination and declination angles of the ambient field were taken as $-15.92^{\circ}$ and $-5.73^{\circ}$ respectively, at the date of January 1970 according to International Geomagnetic Reference Field (IGRF) model referenced to the World Geodetic System 1984 ellipsoid. The aeromagnetic data were geo-referenced to the Universal Transverse Mercator (UTM) coordinate system for comparative study with geological map of the area. A grid cell size of $250 \times 250 \mathrm{~m}$ was used, which is one-third (1/3) of the survey or flight line spacing, so as to avoid short-wavelength errors that may appear as lines perpendicular to the line direction. The TMI map (Figure 4) is characterized by high magnetic anomalies of ENE-WSW trending direction (Mono et al., 2018a). This configuration may be attributed to relatively deep-seated low relief basement structures. The TMI grid data were then transformed using the reduction to the equator (RTE) filter (Figure 5), instead of the reduction to the pole (RTP) filter, since the study area is located within the low magnetic latitudes (i.e. areas with geomagnetic inclination less than 15) where a satisfactory reduction to the pole (RTP) of magnetic data is not possible.

The RTE map (Figure 5) is characterized by a major long wavelength positive anomaly trending NE-SW to E-W. This anomaly extends from Mbaka in the south to Nguélémendouka in the central part and shows the highest amplitude $(110 \mathrm{nT})$ in the south part. This anomaly could also be caused by an intrusion, as gravimetric investigations in the area showed high-density, intrusive-like body at depth (Basseka et al. 2011). We also observe some circular magnetic trends, with magnitudes above $111.60 \mathrm{nT}$. They are found in the south of N'Djombe along $530,000 \mathrm{~m}$ and 520,000 m latitudes. These circular trends with large magnitudes suggest the presence of highly magnetized cylindrical intrusive bodies within the basement. 


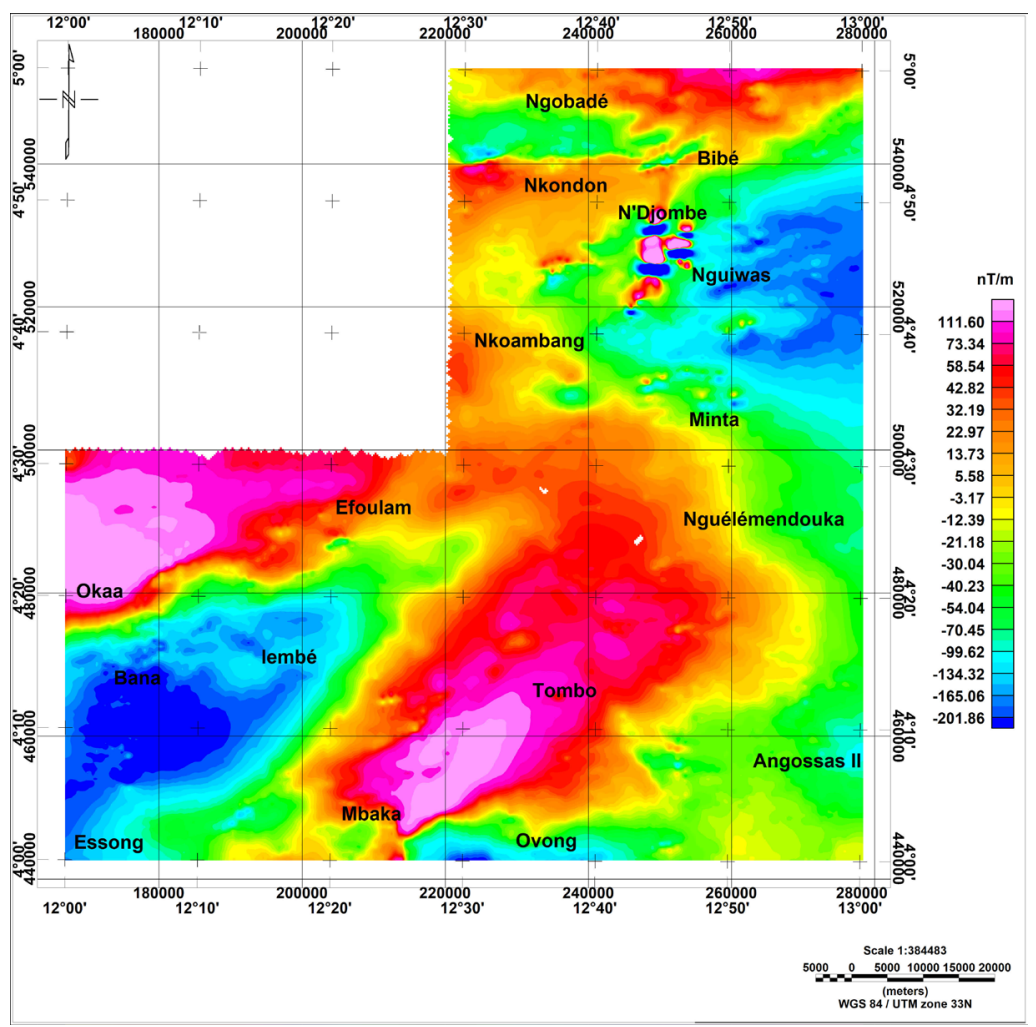

Figure 4. Total magnetic intensity map of the study area.

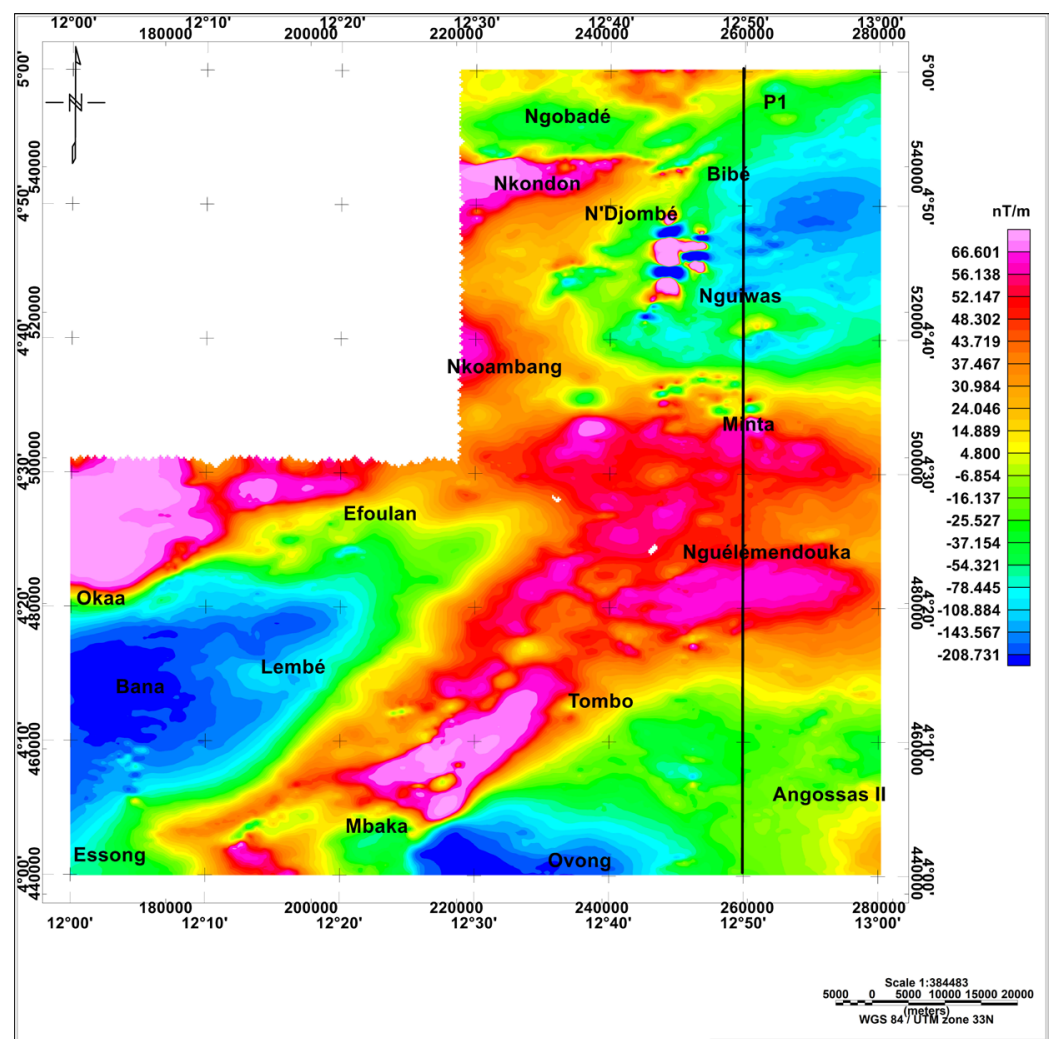

Figure 5. Total magnetic intensity anomaly map reduced to equator. Line P1 corresponds to the profile selected for modeling. 


\subsection{Methods}

\subsubsection{First Vertical Derivative}

The vertical gradient allows, in the absence of intra-sedimentary heterogeneities, to recognize the upper and lower parts of the basement. The interest of map conversions from the magnetic or gravimetric field to a vertical gradient (or first vertical derivative) has long been recognized (Evjen 1936); calculation methods have been proposed and illustrated by Aynard (1953), Baranov (1957) and many others. In order to highlight the shallow lithologies, it is necessary to calculate a new transformation of the anomaly map. This transformation must mitigate or even eliminate the regional component that distorts and sometimes masks the relationships between the geology of a shallow basement and the shape of the anomalies. It is obtained by calculating the vertical gradient $(\partial M / \partial z)$, where $M$ is the magnetic anomaly. This transformation plays a role of amplifier for the high frequencies that is to say for the anomalies of small extension, at least in one of the directions. It is therefore indicated to highlight areas where the basement is close to the surface or deeper and superficial accidents of the base, small lateral extensions, which may continue over great distances.

\subsubsection{Upward Continuation}

The amplitude of a magnetic field above a source varies with altitude as an exponential function of the wavelength. This relationship can be easily exploited with Fourier fast transform filters to recalculate the field at a higher altitude ("upward continuation"). A potential field measured on a given observation plane at a constant height can be recalculated as if the observations were made on a different plane at a higher altitude. As described by Milligan \& Gunn, 1997, the process has a frequency response of $\mathrm{e}^{-h\left(u^{2}+v^{2}\right)}$ (where $\mathrm{h}$ is the elevation). This means that the upward continuation attenuates the high frequency anomalies with respect to the low frequency anomalies and according to Blakely (1996), the shorter the wavelength, the greater the attenuation. The process can be useful for removing the effects of shallow anomalies when details of deeper anomalies are required.

\subsubsection{Power Spectrum Transformation}

The method of radial average power spectrum is used to determine the depths of volcanic intrusions, depths of the basement complex and the subsurface geological structures. The fast Fourier transformation (FFT) was applied on the RTE aeromagnetic survey data to calculate the energy spectrum. As a result, a two-dimensional power spectrum curve was obtained. Based on the appearance of the spectrum, (i.e. change in the slope of the spectrum curve), the slopes of the segments yield estimates of the average depths to magnetic sources.

The depth of each source ensemble responsible for each segment was calculated by introducing the slope of this segment in the formula:

$$
H(\text { depth })=-\frac{\text { slope }}{4 \pi}
$$




\subsubsection{Modelling 2.75D}

Geophysical modelling is a powerful tool for proposing a hypothesis on the geometry of the bodies responsible for magnetic anomalies in depth. It allows seeing in section in a detailed way how the different units are superimposed. Model 2.75D calculates the magnetic anomalies induced by geometric objects according to their shape, their depth and the petrophysical characteristics attributed to them. The magnetic effect generated by these objects is calculated and compared to the measured signals. These objects are then interpreted as geological bodies. However, if no external information comes to constrain the model, there is theoretically an infinity of models that can explain an anomaly. For this reason, it is essential to inject into the model the maximum amount of information to obtain as constrained models as possible. The constraints can be of various natures: structural, lithological, elements of geometry, depth or petrophysical characteristics assigned to a body. This is why the lithological maps are a valuable anchor for the realization of model $2.75 \mathrm{D}$ profiles according to realistic hypotheses. These maps constrain the structures and lithologies expected in depth. In addition to these maps, petrophysical characteristics determined in the field constrain the magnetic susceptibility values attributed to the modelled bodies.

\section{Results and Discussion}

\subsection{The First Vertical Derivative}

The vertical derivative is a so-called focusing transformation that favors the high frequencies contained in the initial data. The following advantages result: it increases the separating power that is to say, it makes it possible to separate the close and coalescent anomalies; it favors the effect of superficial sources to the detriment of deep sources and regional effects. Figure 6 is the result of this technique. This map highlights the anomalies of variable size, shape and amplitude. The boundaries between the different geological units are generally more noticeable. We can clearly distinguish anomalies of linear and pseudo-circular shapes characterized by amplitude values ranging between -0.051 and +0.042 nT.

This map shows more restricted and highly individualized anomalies that were almost invisible on the maps of anomalies of the total magnetic field and total magnetic field reduced to the equator. This situation is highlighted north and south of the study area. In Nguiwas and north-east of Nguiwas, numerous sub-horizontal orientation anomalies and ENE-WSW emerged. The disappearance of the large positive and negative anomalies on the maps of anomalies of the total magnetic field and RTE magnetic confirms that they are related to deep structures. The presence of strong pseudo-circular anomalies of N'Djombe-Nguiwas confirms that they are associated with superficial sources.

In Mbaka, we encounter the same phenomenon, in the centre of the map, there is always a large area of positive anomaly EW and NE-SW as on RTE magnetic map, to the only difference that it is interrupted by negative anomalies 


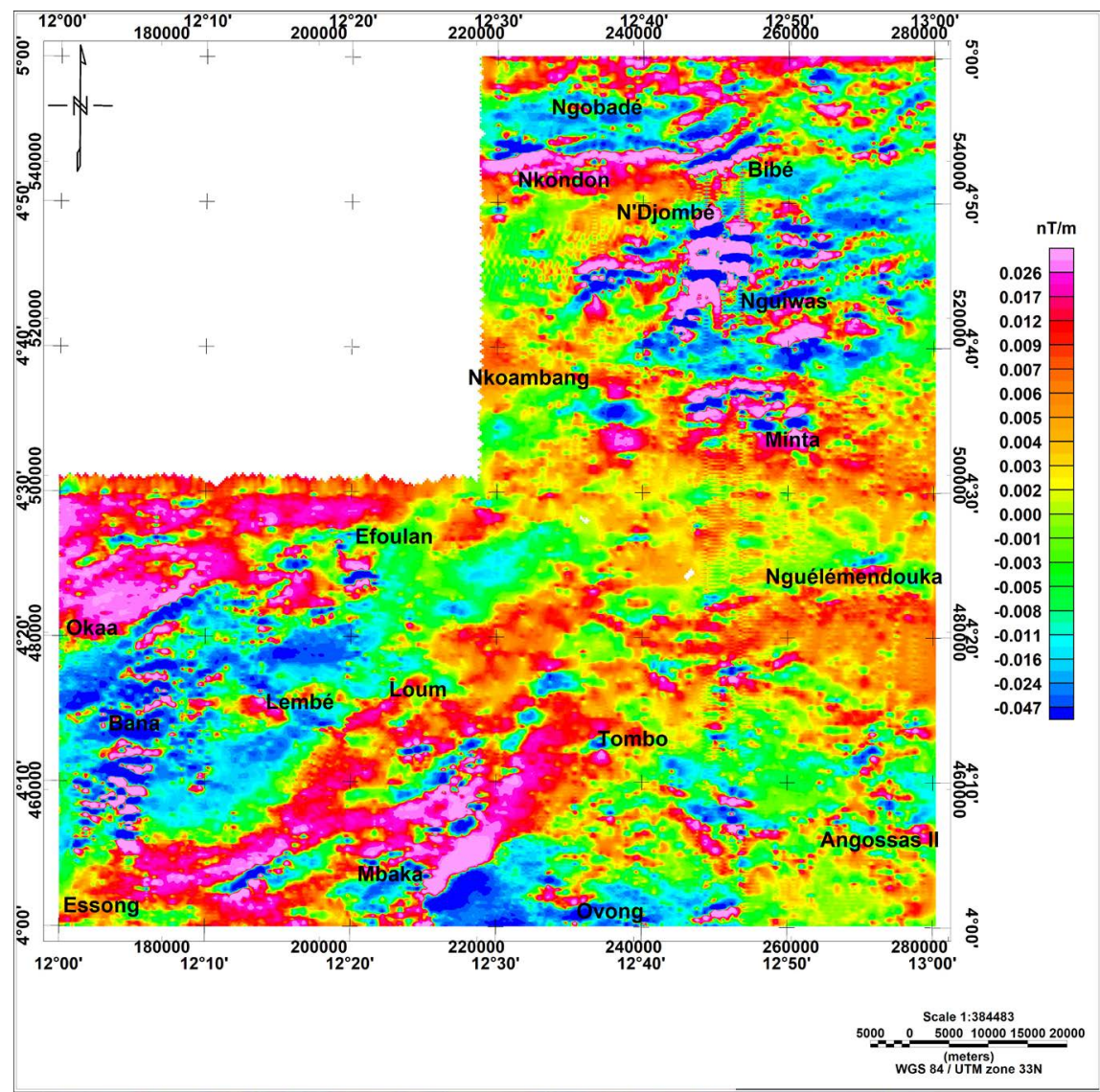

Figure 6. First vertical derivative map.

of varied amplitude, of fine and elongated form of shallow sources. The vertical gradient clearly shows the contrast between strongly magnetized and non-magnetic regions. These strongly magnetic zones are bordered by zones with vertical gradients reduced to the negative equator. This organization of magnetic anomalies is a normal sign of the vertical gradient and should not be interpreted in terms of lithological variation. The greater the amplitude of the negative peripheral zones, the more the structure they surround is limited downwards. This particular magnetic structuring thus provides information on the thickness of the magnetized structures that are appreciated. This is particularly visible in Ngobadé, Bibé, Nguiwas and Ovong.

\subsection{Upward Continued Maps}

The upward continuation is equivalent to filtering of the high frequencies of the field associated with the effects of the superficial magnetic structures, to show only the effects of the deep structures.

Figure 7 presents the magnetic field anomaly maps reduced to the equator of the study area, continued respectively to $1 \mathrm{~km}, 2 \mathrm{~km}$ and $4 \mathrm{~km}$ altitudes. The general observation of the downwardly continued equator magnetic field anomaly maps shows that as the prolongation altitude increases, the localized anomalies are strongly attenuated and fade away. Larger wavelength anomalies are 
J. A. Mono et al.

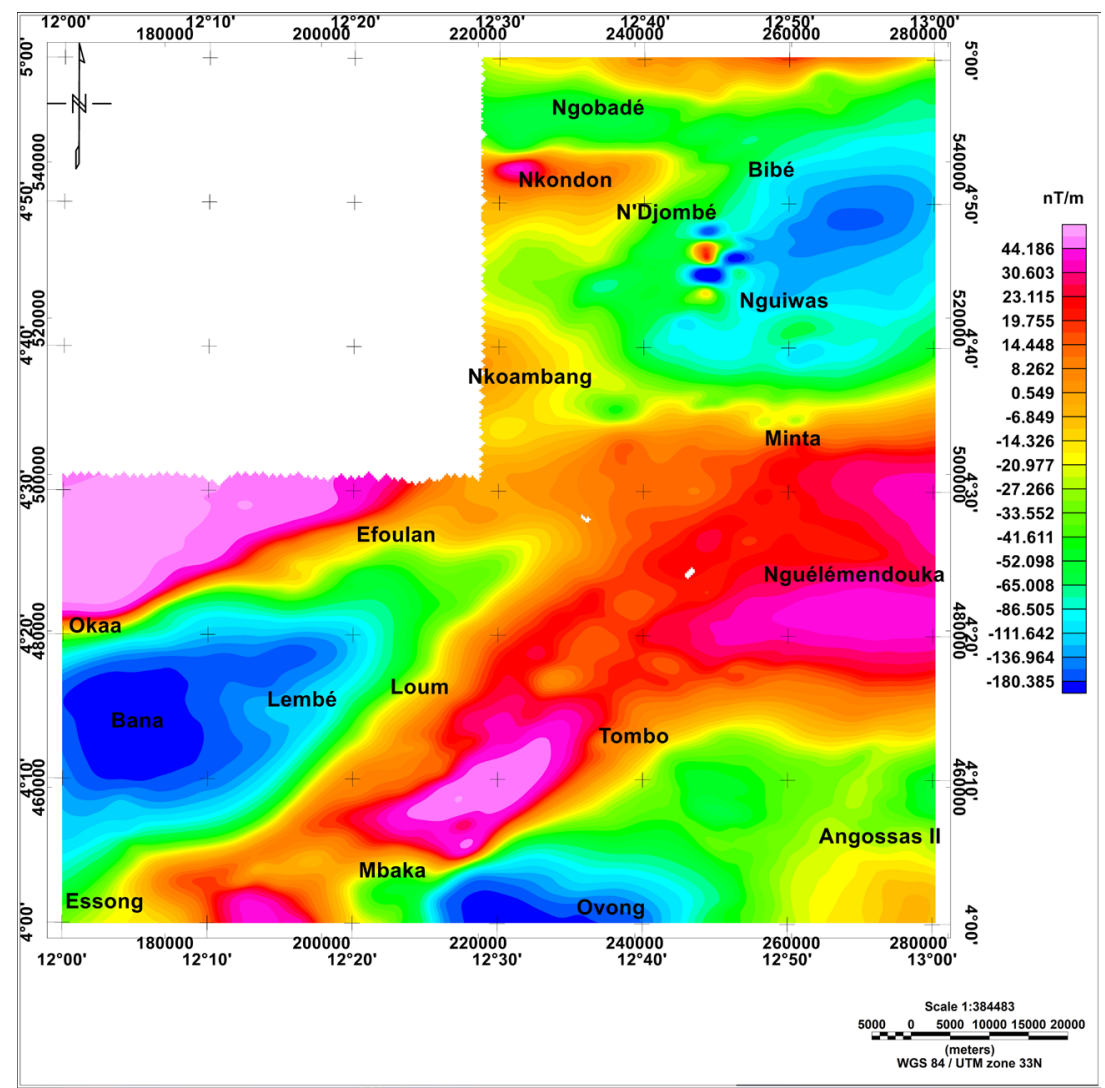

(a)

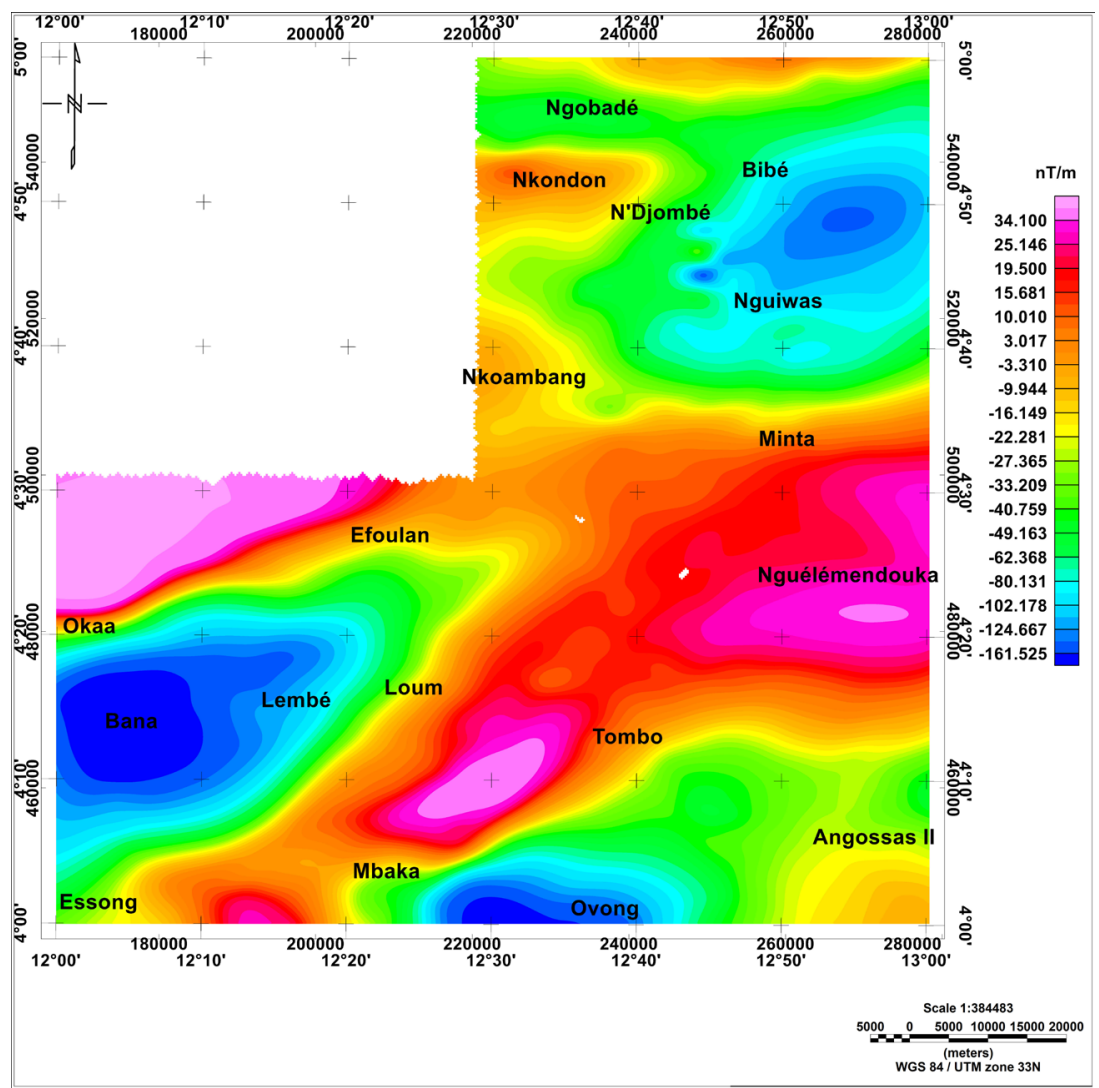

(b) 


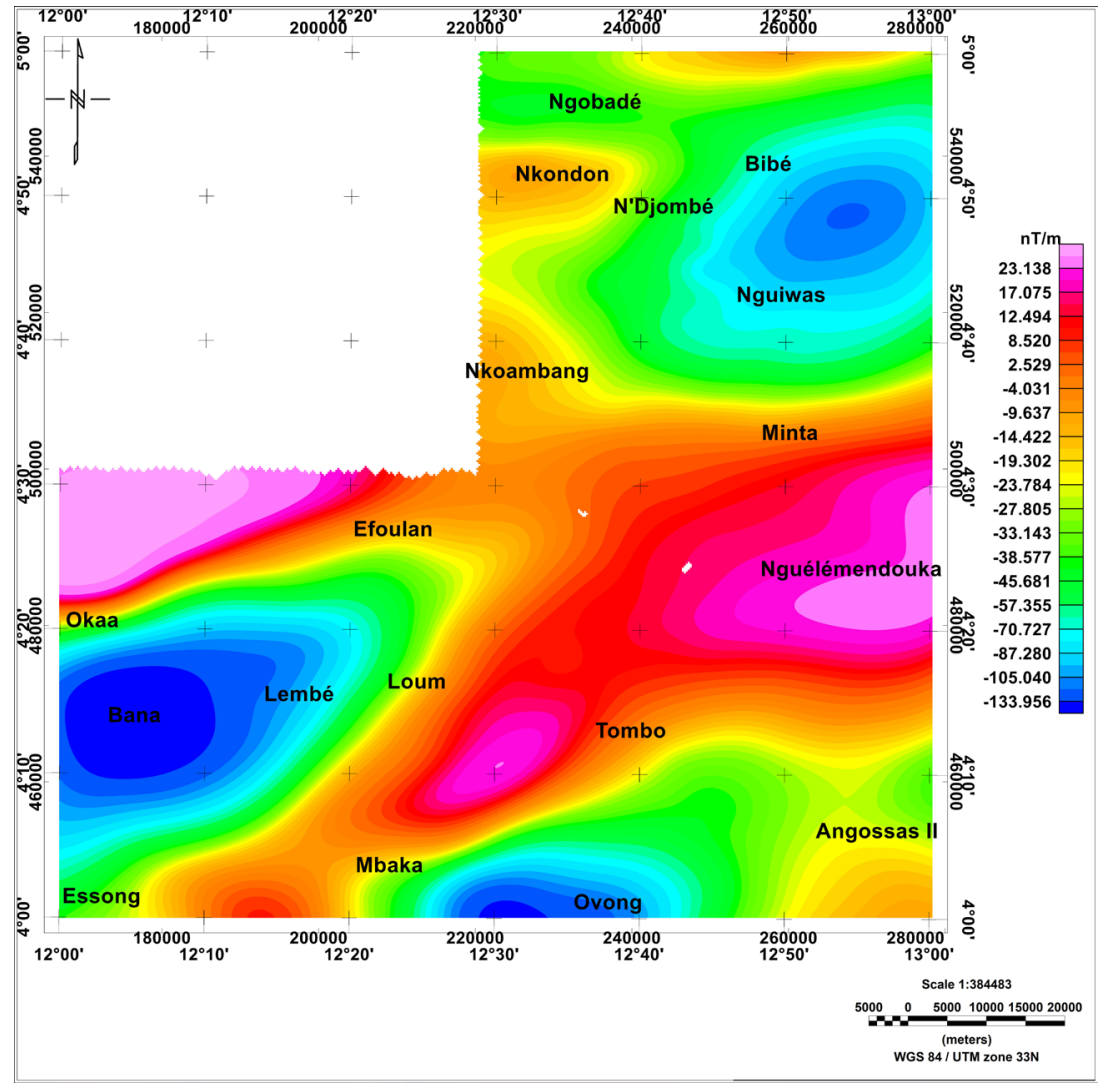

(c)

Figure 7. Upward continued map at: (a) $1 \mathrm{~km}$; (b) $2 \mathrm{~km}$ (c) $4 \mathrm{~km}$.

smoothed. The different orientations of the anomalies are almost the same as those found on the map of anomalies reduced to the equator. We observe that:

- the positive anomaly of Ngobadé is still marked on the extended map at 1 $\mathrm{km}$, it fades over the extended map at $2 \mathrm{~km}$ and $4 \mathrm{~km}$ suggesting a shallow source for this anomaly;

- Nkondon's positive anomaly fades over the extended map at $1 \mathrm{~km}, 2 \mathrm{~km}$ and $4 \mathrm{~km}$ suggesting a shallow source for this anomaly;

- The positive and negative, well-individualized circular anomalies of N'Djombé-Nguiwas fade considerably over the extended map at $1 \mathrm{~km}$ and disappear completely at altitudes of $2 \mathrm{~km}$ and $4 \mathrm{~km}$. This is because these sources of anomalies are superficial;

- the two large negative anomalies of Bana and the one located in the north-east of the study area, as well as that of Ovong (less extensive), persist on the extended map at $1 \mathrm{~km}, 2 \mathrm{~km}$ and $4 \mathrm{~km}$ which suggest that they are related to root causes;

- the large positive anomaly in the center of the area is gaining in volume and the one located north of Oka'a has hardly changed shape as the prolongation altitude increases, suggesting a deep origin for these anomalies.

In a general way, the upward continued makes it possible to affirm that the effect of the superficial structures is masked by the effect of the deep structures, 
this can be due to the small thickness of the superficial structures which does not allow to cause significant changes to the magnetic field.

\subsection{Analysis of Power Spectrum Transformation}

The power spectrum map was computed using Geosoft/Oasis Montaj V8.5 software. The calculated radially-averaged power spectrum for the RTE magnetic mapis shown in (Figure 8). It could be divided into three segments. A very steep part (red segment) is in the frequency range of 0.0 to $0.1 \mathrm{cycle} / \mathrm{km}$ which represents the long wavelengths that are deep sources component. The slope of this segment reflects the maximum depth which equals 12,000 $\mathrm{m}$ (Figure 8) and probably represents the Curie point depth. A less steep part (blue segment) lies in the frequency range 0.1 to $0.9 \mathrm{cycle} / \mathrm{km}$ which represents the short wavelengths that is called shallow sources component. Its slope relates to the mean depths of shallow sources which represent the minimum depth to basement complex and found to be $2500 \mathrm{~m}$ (Figure 8). The third segment, which possesses frequencies exceeding $0.9 \mathrm{cycle} / \mathrm{km}$, represents the noise component.

\subsection{Magnetic Lineaments Map}

The results of the recent work done by Mono et al. (2018b) namely, the superposition of the maxima of the horizontal gradient coupled with the upward extension at different altitudes on the one hand and the deconvolution of Euler on the other hand allowed us to obtain the map of the lineaments (Figure 9) of the study area by simple tracing on the local maxima obtained from the two complementary methods. The solutions resulting from these two methods made it
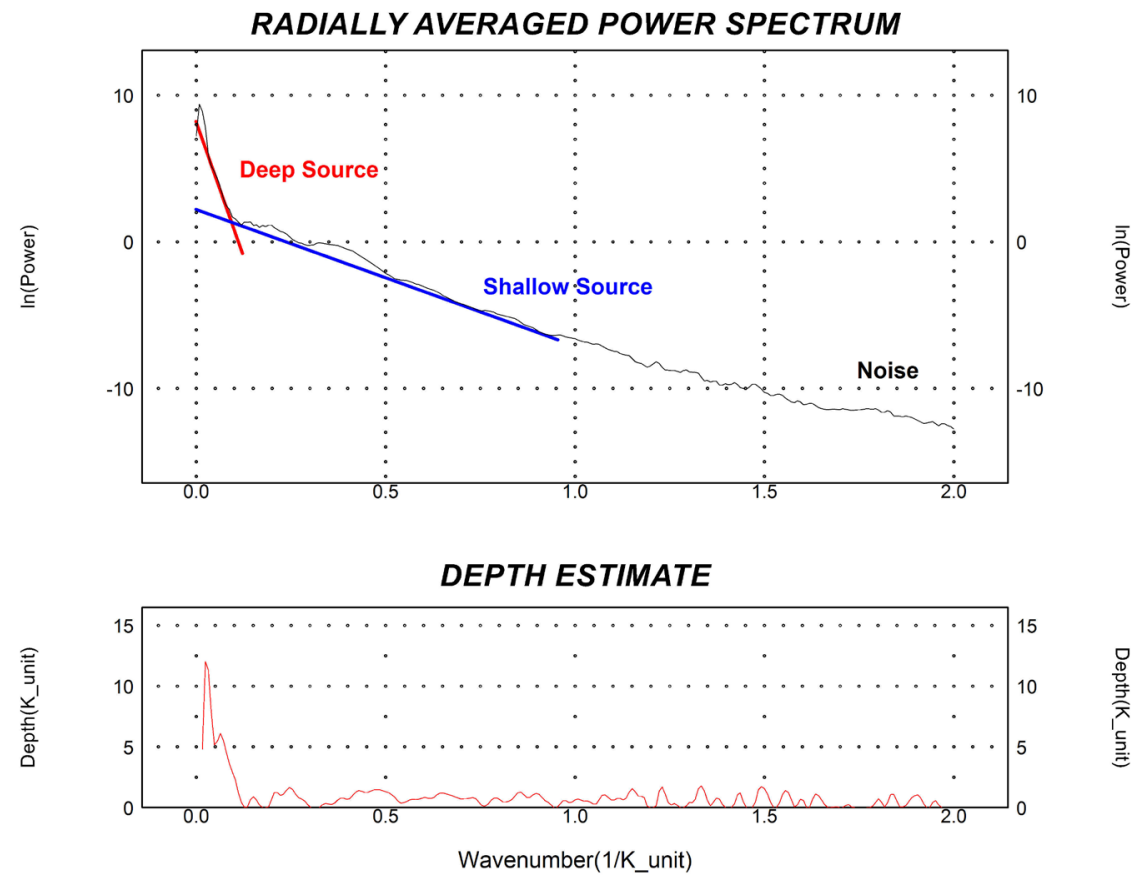

Figure 8. Power spectrum showing the mean depth to the basement rock in the study area. 


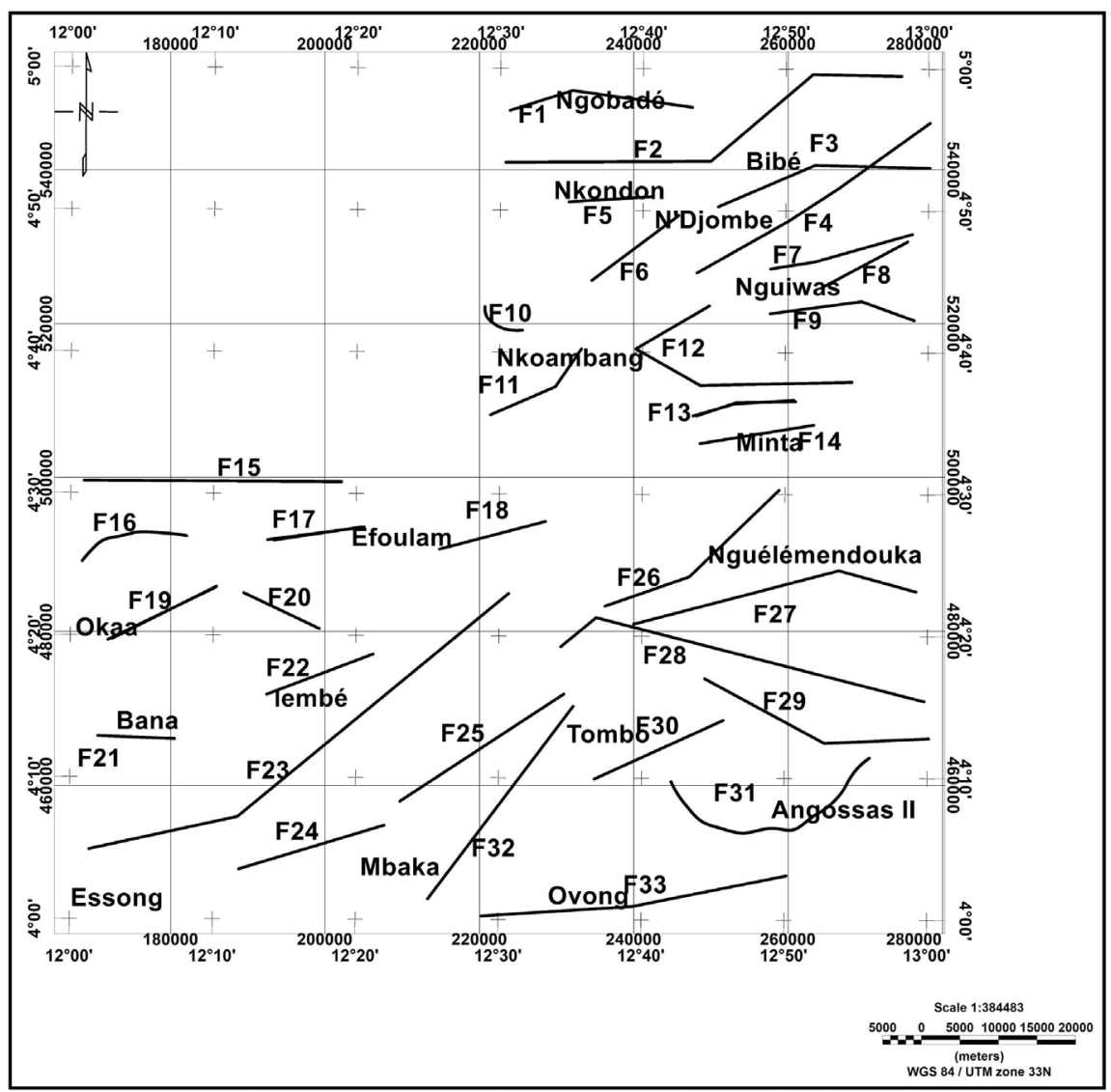

Figure 9. Magnetic lineaments map of the area study.

possible to characterize the faults (Table 1 ) thus reflecting in a general way the structural and tectonic aspect of the area of study.

The map in Figure 9 summarizes the main tectonic events characterizing the subsoil of the study area. These accidents are interpreted as dykes, faults, contacts or boundaries between geological formations. Their directions are respectively E-W, ENE-WSW, NE-SW, WNW-ESE and NW-SE. The installation of these corridors testifies the tectonic events of the region (Regnoult, 1986, Meying et al., 2009, Ndougsa et al., 2014).

An analysis of the magnetic lineaments map of the study area from the structural and tectonic point of view indicates that the study area is strongly affected by faults, fault folds and dykes along the directions mentioned above. Here, some sets of faults and folds follow the predominant structural trends E-W and ENE-WSW, which are two major axes inherited from the different tectonic events occurring in this region. From the tectonic point of view, the different trends highlighted on the interpretive structural map suggest that the area has been subjected to significant regional tectonic stress.

\subsection{Magnetic Lineaments Superimposed on Magnetic Anomalies}

The superimposition of the maps of the lineaments on the RTE magnetic map (Figure 10) shows that the lineaments generally follow the directions of the 
Table 1. Directions and characteristics of the main faults identified.

\begin{tabular}{|c|c|c|}
\hline $\mathrm{N}^{\circ}$ Faults & Dip & Average depth \\
\hline $\mathrm{F} 1$ & Vertical & $900 \mathrm{~m}$ \\
\hline F2 & Vertical & $800 \mathrm{~m}$ \\
\hline F3 & North-west & $900 \mathrm{~m}$ \\
\hline F4 & Vertical & $240 \mathrm{~m}$ \\
\hline F5 & Vertical & $190 \mathrm{~m}$ \\
\hline F6 & Vertical & $260 \mathrm{~m}$ \\
\hline F7 & Vertical & $200 \mathrm{~m}$ \\
\hline F8 & Vertical & $900 \mathrm{~m}$ \\
\hline F9 & North-south & $350 \mathrm{~m}$ \\
\hline F10 & Vertical & $1800 \mathrm{~m}$ \\
\hline F11 & Vertical & $1500 \mathrm{~m}$ \\
\hline F12 & Vertical & $210 \mathrm{~m}$ \\
\hline F13 & Vertical & $200 \mathrm{~m}$ \\
\hline F14 & Vertical & $240 \mathrm{~m}$ \\
\hline F15 & Vertical & $1400 \mathrm{~m}$ \\
\hline F16 & Vertical & $700 \mathrm{~m}$ \\
\hline F17 & North-west & $1800 \mathrm{~m}$ \\
\hline F18 & Vertical & $2200 \mathrm{~m}$ \\
\hline F19 & Vertical & $900 \mathrm{~m}$ \\
\hline F20 & Vertical & $2300 \mathrm{~m}$ \\
\hline F21 & Vertical & $300 \mathrm{~m}$ \\
\hline F22 & Vertical & $1800 \mathrm{~m}$ \\
\hline F23 & Vertical & $800 \mathrm{~m}$ \\
\hline F24 & Vertical & $1500 \mathrm{~m}$ \\
\hline F25 & South-west & $700 \mathrm{~m}$ \\
\hline F26 & Vertical & $400 \mathrm{~m}$ \\
\hline F27 & Vertical & $700 \mathrm{~m}$ \\
\hline F28 & North-west & $800 \mathrm{~m}$ \\
\hline F29 & Vertical & $1400 \mathrm{~m}$ \\
\hline F30 & Vertical & $1000 \mathrm{~m}$ \\
\hline F31 & Vertical & $200 \mathrm{~m}$ \\
\hline F32 & Vertical & $1500 \mathrm{~m}$ \\
\hline F33 & South-west & $1100 \mathrm{~m}$ \\
\hline
\end{tabular}

different gradients highlighted on RTE magnetic map. It also appears that all areas strongly magnetized or not, are affected by regional tectonics. 


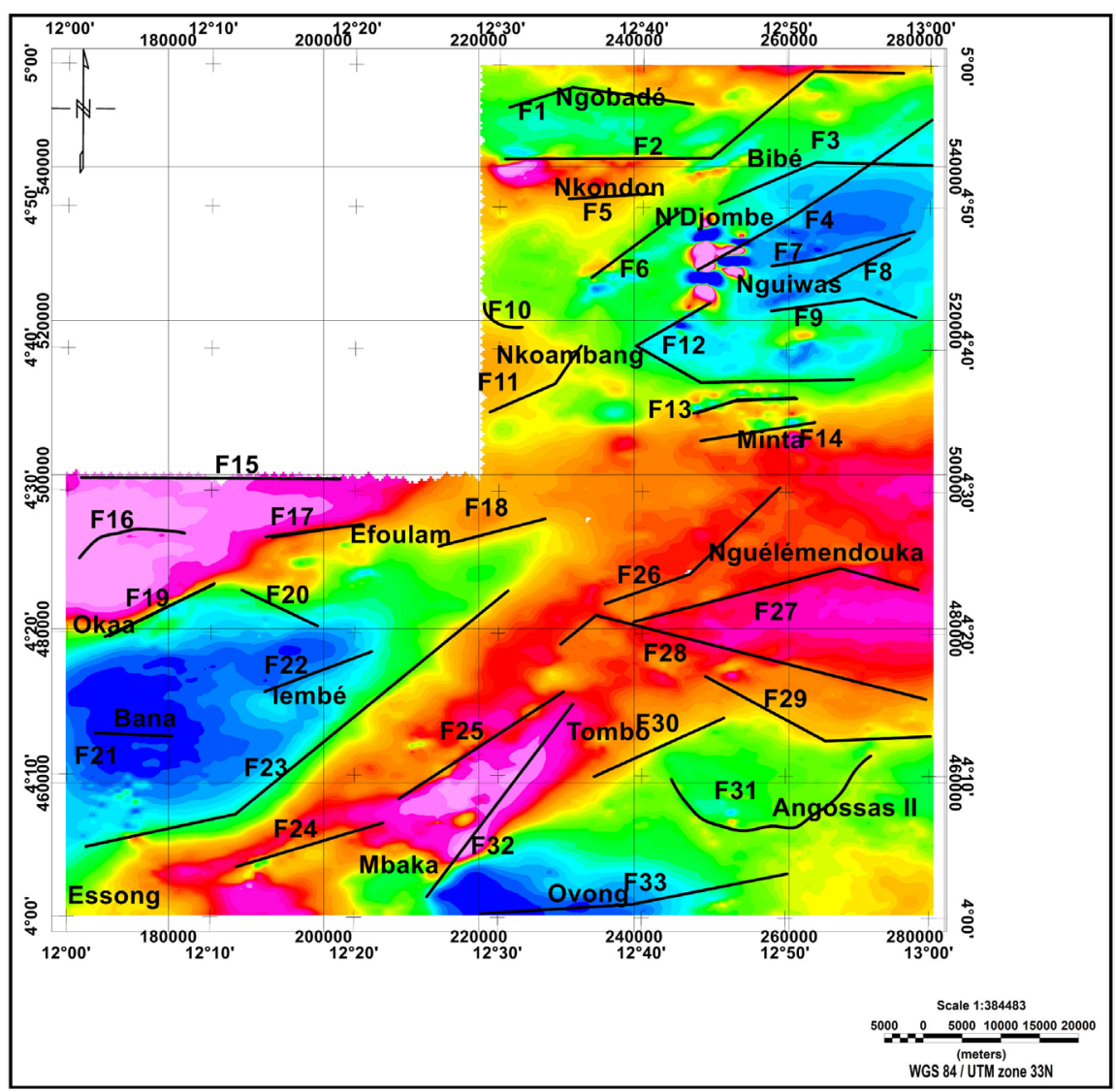

Figure 10. Map of magnetic lineaments superimposed on RTE magnetic map.

\subsection{Magnetic Lineaments and Geology}

The map of the magnetic lineaments was superimposed on the geological map to obtain the interpretative structural map of the region (Figure 11). This map summarizes the main boundaries between areas with a high magnetic susceptibility contrast under the ground and several of these limits correspond to tectonic accidents. It confirms and specifies the layout of brittle structures resulting from previous geological and geophysical studies and highlights new accidents not detected by geological studies. These accidents are organized as follows:

1) The E-W direction is that of the oldest faults of the Pan-African Chain. It is one of the major trends in the region. The E-W directional faults are centred north of the study area on migmatite and gneiss formations: they are F1, F5 F13, F14 F15, F21 and F17 faults that can reach $1700 \mathrm{~m}$ depth.

2) These main accidents associated with trans-African lineaments of Central Africa constitute a bundle of major structures generally brittle. At the regional scale, they determine a vast tectonic corridor oriented substantially E-W of some $5000 \mathrm{~km}$ long. These structures are generally underlined by Precambrian mylonites and materialized from southern Cameroon to central Sudan, the North Equatorial orogenic zone, of pan-African age bordering, in the north, the Craton of the Congo. The significance of these faults is closely related to the geodynamic evolution of the Pan African chain of Central Africa (Mbom-abane, 1997). 


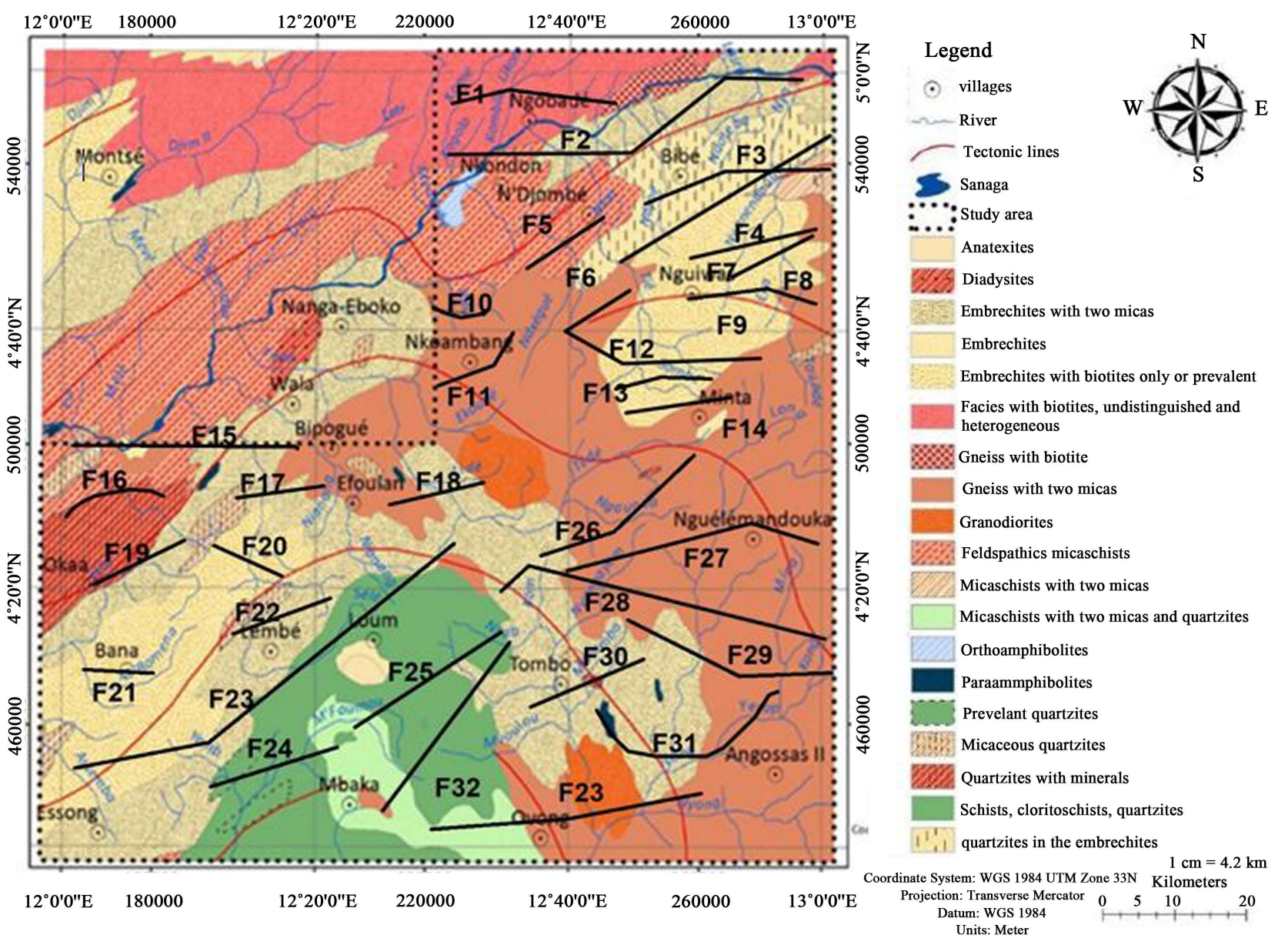

Figure 11. Structural interpretative geological map of the area.

3) In the study area, the ENE-WSW fault bundle is represented by 17 different faults, most of them normal.

4) The F27 fault, which is more than $37 \mathrm{~km}$ long, is located on the anatexites at about $800 \mathrm{~m}$ depth. Its orientation is approximately ENE-WSW and twists to point WNW-ESE. It is south-southeast convex and vertical dip.

5) We observe the ENE-WSW faults associated with F4, F7, F8, F9, F11, F18, F19, F22, F24, F30, and F33 of variable depths. These very extensive accidents have extensions that vary between 20 and $50 \mathrm{~km}$ and depths can reach $2400 \mathrm{~m}$.

6) The ENE-WSW direction is associated with structural deformations under the craton (Feumoe, 2012). The presence in the study area of ENE-WSW management accidents could be related to the presence of Craton under the study area.

7) NE-SW accidents represented by faults F4, F6, F25, F26 and F32. These faults are minor with depths up to $1500 \mathrm{~m}$.

8) The faults represented by F20 and F29 are minor accidents. They are NW-SE direction for the F20 fault and the F29 fault for NW-SE then E-W. Their depth is respectively around $2300 \mathrm{~m}$ and $1400 \mathrm{~m}$.

9) The F28 fault, which outcrops for $50 \mathrm{~km}$, is oriented WNW-ESE and twists 
to orient itself NE-SW. This accident is north-westerly and is vertically dipping, with a depth of approximately $800 \mathrm{~m}$.

10) The shape of F10, F16 and F31 suggests intrusions or diapirs in the basement of the study area.

\subsection{Modelling}

GM-SYS is the program used in our work for the modelling of magnetic sources. GM-SYS is a module of the software Oasis Montaj V8.4 (Geosoft), it is based on a direct calculation model. The methods used by GM-SYS to calculate the magnetic model response are based on the methods of Talwani et al. (1959) and Talwani \& Heirtzler (1964) and make use of the algorithms described in Won \& Bevis (1987). Two-and-a-half dimensional calculations are based on Rasmussen \& Pedersen (1979). This program makes it possible to model the geometry as well as the physical parameters of blocks located in depth, in an interactive way. The model is done along profiles intersecting the data grids.

In direction S-N, the profile $\mathrm{P} 1$ has a length of $11,000.05 \mathrm{~m}$ and comprises 100 experimental points (Figure 12). Distances are given in $\mathrm{m}, 0 \mathrm{~m}$ corresponding to the southern end of the section. This profile has its origin in the south of the study area in the locality of Angossas II and crosses the localities of Nguélémendouka, Minta, Nguiwas and Bibé. Its northern end is located in the area of Bibé.

The profile of the magnetic anomaly has a long wavelength of variable intensity between 52,348 $\mathrm{m}$ and $117,160 \mathrm{~m}$ (Figure 12) whose maximum reaches an intensity of $44.77 \mathrm{nT}$. Two large zones of negative anomalies are also observed along $\mathrm{P} 1$, one located between 0 and $27,371 \mathrm{~m}$ with a negative intensity peak of $-44.12 \mathrm{nT}$ and the other located between $61,822 \mathrm{~m}$ and $107,000 \mathrm{~m}$ with a Negative peak intensity of $-192.32 \mathrm{nT}$ at $79232 \mathrm{~m}$. Interpretations of geophysical and geological sections are commented from south to north.
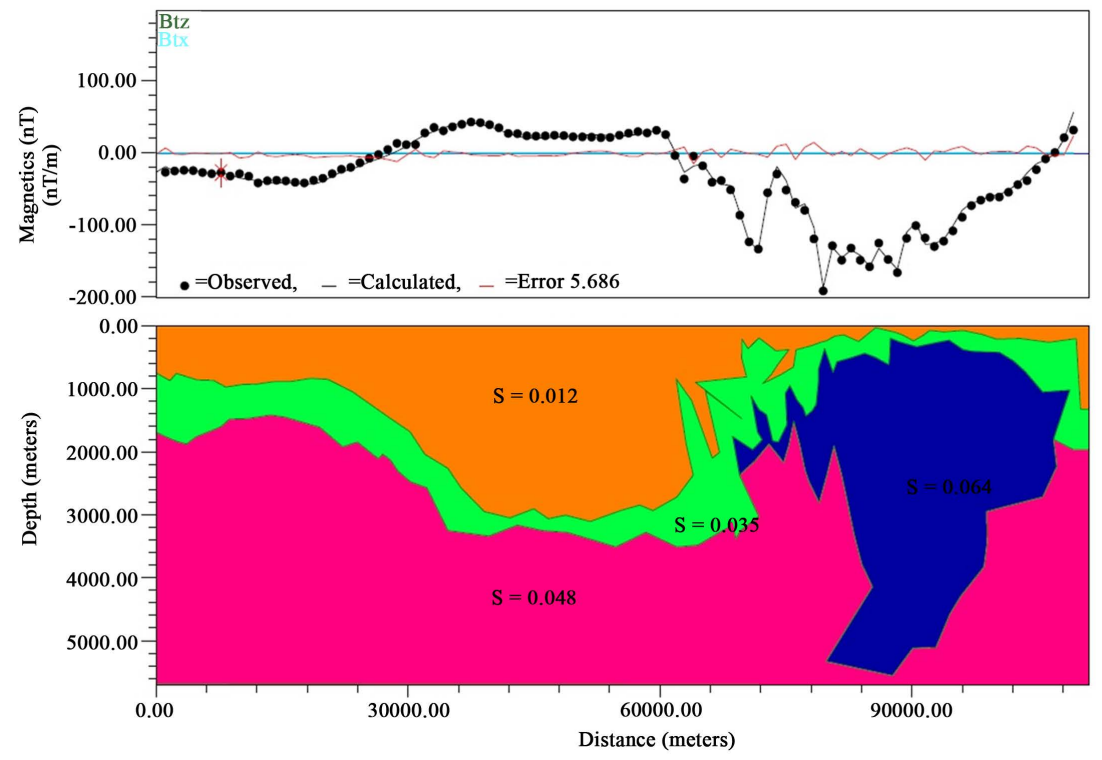

Figure 12. Modelling along profile P1. 
A careful analysis of this profile shows an excellent fit between observed and calculated anomalies with an acceptable error of 5.68 (Figure 12). The profile also crosses from the surface to the subsoil three successive geological units of respective susceptibility 0.012 SI, 0.035 SI and 0.048 SI. However, we note the presence of a body of high magnetic susceptibility with a value of 0.064 SI located at a depth of $207 \mathrm{~m}$ with an extension of 40,163 m. Starting from the ranges and average values of the magnetic susceptibilities of the rocks given by the scientific literature and by taking into account the geological context of the study area marked by a large fault system, such a contrast is due to an intrusion in the crust of a large body of high susceptibility.

The first geological formation of average susceptibility 0.012 SI goes from the surface to a depth of $3125 \mathrm{~m}$. The second geological unit is at a minimum depth of $67 \mathrm{~m}$ and its upper interface is at a depth of between $3505.26 \mathrm{~m}$ and $67 \mathrm{~m}$. The third formation represents the base, its average susceptibility is $0.048 \mathrm{SI}$, indicating that it is granite.

\section{Conclusion}

The interpretation of magnetic anomalies in central-eastern Cameroon (Loum-Minta) from aeromagnetic data was made by the use of several operators: the reduction at the equator, which allowed to have a magnetic recognition of the region; then, the first vertical derivative, the upward extension, the spectral analysis and the $2 \mathrm{D}^{3 / 4}$ modeling which facilitated the analysis of the behavior of the various anomalies as well as their interpretation. In the same way, the development of an interpretive structural map allowed to have a regional overview of the extensions, orientations and characteristics of the lineaments. The upward extension at various altitudes enabled us to confirm that the effect of the superficial sources is masked by that of the deep sources given the weak correlation between the map of anomalies of the total magnetic field reduced to the equator and the geological map of the region. The spectral analysis allowed estimating the depths of the sources of superficial and deep magnetic anomalies. They are $2500 \mathrm{~m}$ and $12000 \mathrm{~m}$ respectively. The $2 \mathrm{D}^{3 / 4}$ model has made it possible to obtain the geometry of the structures responsible of the anomalies observed along a profile. We note the presence of a body of high magnetic susceptibility with a value of 0.064 SI located at a depth of $207 \mathrm{~m}$. The structural map of the area has identified a large number of lineaments whose regional characteristics, orientations and extensions were previously unknown.

\section{Acknowledgements}

The authors are grateful to the reviewers and the readership for their kind help in making the manuscript clearer, more correct and mature for publication.

\section{Conflicts of Interest}

The authors declare that there is no conflict of interest regarding the publication of this paper. 


\section{References}

Aynard, C. (1953). An Attempt to Interpret the Gravimetric Map of the Northern Part of the Moroccan Basin of Ghareb. Maps of the Residual Anomaly and First Vertical Derivative. Geophysical Prospecting, 1, 279-289. https://doi.org/10.1111/j.1365-2478.1953.tb01148.x

Baranov, V. (1957). A New Method for Interpretation of Aeromagnetic Map: Pseudogravimetric Anomalies. Geophysics, 22, 359-383. https://doi.org/10.1190/1.1438369

Basseka, C. A., Shandini, Y., \& Tadjou, J. M. (2011). Subsurface Structural Mapping Using Gravity Data of the Northern Edge of the Congo Craton, South Cameroon. Geofizika, 28, 229-245.

Blakely, R. J. (1996). Potential Theory in Gravity and Magnetic Applications (441 p.). Cambridge: Cambridge University Press.

Evjen, H. M. (1936). The Place of the Vertical Gradient in Gravitational Interpretations. Geophysics, 1, 127-136. https://doi.org/10.1190/1.1437067

Feybesse, J. L., Johan, V., triboulet, C., Guerrot, C., Mayaga-mikolo, F., Bouchot, V., \& Eko n'dong, J. (1998). The West Central Africa Belts: A Model of 2.5-2.0 Ga Accretion and Two-Phase Orogenic Evolution. Precambrian Research, 87, 161-216. https://doi.org/10.1016/S0301-9268(97)00053-3

Kwekam, M., Liégeois, J.-P., Njonfang, E., Affaton, P., Hartmann, G., \& Tchoua, F. (2010). Nature, Origin and Significance of the Fomopéa Pan-African High-K Calc-Alkaline Plutonic Complex in the Central African Fold Belt (Cameroon). Journal African Earth Sciences, 57, 79-95. https://doi.org/10.1016/j.jafrearsci.2009.07.012

Maurizot, P., Abessolo, A., Feybesse, J. L., Johan, J., \& Lecomte, P. (1986). Mining Study and Prospecting of South-West Cameroon, Synthesis of Work from 1978 to 1985, 1986 (274 p.). BRGM, Report 85 CMR 066.

Mbom-Abane, S. (1997). Geophysical Investigation on the Edge of the Craton Congo Region of Abong-Mbang/Akonolinga, Cameroon and Structural Implications. PhD Thesis, Yaoundé: University of Yaoundé I.

Meying, A., NdougsaMbarga, T., \& Manguelle-Dicoum, E. (2009). Evidence of Fractures from the Image of the Subsurface in the Akonolinga-Ayos Area Cameroon by Combining the Classical and the Bostick Approaches in the Interpretation of Audiomagnetotelluric Data. Journal of Geology and Mining Research, 18, 159-171.

Milligan, P. R., \& Gunn, P. J. (1997). Enhancement and Presentation of Airborne Gophysical. AGSO Journal of Australian Geology \& Geophysics, 17, 63-75.

Mono, J. A., Ndougsa-Mbarga, T., Bikoro Bi-Alou, M., Ngoh, J. D., \& Owono, O. U. (2018). Inferring the Subsurface Basement Depth and the Contact Locations from Aeromagnetic Data over Loum-Minta Area (Centre-East Cameroon). International Journal of Geosciences, 9, 869-887. https://doi.org/10.4236/ijg.2018.97028

Mono, J. A., Ndougsa-Mbarga, T., Meying, A., Bikoro Bi-Alou, M., Ngoh, J. D., \& Owono, O. U. (2018b). Evidence by Multi-Scale Analysis of Structural Features Derived from Aeromagnetic Anomalies in Loum-Minta (Centre-East Cameroon). Arabian Journal of Geosciences. (Under Review)

Mvondo, H., Den-Brok, S. W. J., \& Mvondo-Ondoa, J. (2003). Evidence for Symmetric Extension and Exhumation of the Yaoundé Nappe (Pan-African Fold Belt, Cameroon). Journal of African Earth Sciences, 36, 215-231. https://doi.org/10.1016/S0899-5362(03)00017-4

Mvondo, H., Owona, S., Mvondo-Ondoa, J., Essono, J., \& Yene-Atangana, J. Q. (2007). Comment on $\mathrm{U}-\mathrm{Pb}$ Dating of Plutonic Rocks Involved in the Nappe Tectonic in 
Southern Cameroon: Consequence for the Pan-African Orogenic Evolution of the Central African Fold Belt. Journal of African Earth Sciences, 44, 479-493.

Ndougsa-Mbarga, T., Meying, A., Bisso, D., Sharma, K. K., Layu, D. Y., \& Manguelle-Dicoum, E. (2011). Audiomagnetotelluric (AMT) Soundings Based on the Bostick Approach and Evidence of Tectonic Features along the Northern Edge of the Congo Craton, in the Messamena/Abong-Mbang. The Journal of Indian Geophysical Union, 15, 145-159.

Ndougsa-Mbarga, T., YufenyiuLayu, D., Quentin Yene-Atangana, J., \& Tabod, C. (2014). Delineation of the Northern Limit of the Congo Craton Based on Spectral Analysis and 2.5 D Modeling of Aeromagnetic Data in the Akonolinga-Mbama Area, Cameroon. Geofísicainternacional, 53, 5-16. https://doi.org/10.1016/S0016-7169(14)71486-2

Owona, S. (2008). Archaean, Eburnean and Pan-African Features and Relationships in Their Junction Zone in the South of Yaoundé (Cameroon) (232 p.). PhD Thesis, Douala: University of Douala.

Poidevin, J. L. (1983). Pan-African Tectonics at the Northern Congo Craton Boundary. The Orogeny of the "Oubanguide".

Rasmussen, R., \& Pedersen, L. B. (1979). End Corrections in Potential Field Modeling. Geophysical Prospecting, 27, 749-760. https://doi.org/10.1111/j.1365-2478.1979.tb00994.x

Regnoult, J. M. (1986). Geological Synthesis of Cameroon (119 p.). Yaoundé: Ministry of Mines, Water and Energy, Direction of Mines and Geology.

Shandini, N. Y., Tadjou, J. M., Tabod, C. T., \& Fairhead, J. D. (2010). Gravity Data Interpretation in the Northern Edge of the Congo Craton, South-Cameroon. Anuário do Instituto de Geociências, 33, 73-82.

Tadjou, J. M., Nouayou, R., Kamguia, J., Kande, H. L., \& Manguelle-Dicoum, E. (2009). Gravity Analysis of the Boundary between the Congo Craton and the Pan African Belt of Cameroon. Austrian Journal of Earth Sciences, 102, 71-79.

Talwani, M., \& Heirtzler, J. R. (1964). Computation of Magnetic Anomalies Caused by Two Dimensional Bodies of Arbitrary Shape. In G. A. Parks (Ed.), Computers in the Mineral Industries, Part 1 (pp. 464-480). Stanford Univ. Publ., Geological Sciences 9.

Talwani, M., Worzel, J. L., \& Landisman, M. (1959). Rapid Gravity Computations for Two Dimensional Bodies with Application to the Mendocino Submarine Fracture Zone. Journal Geophysical Research, 64, 49-59.

https://doi.org/10.1029/JZ064i001p00049

Vicat, J. P. (1998). Geological Sketch of Cameroon, GEOCAM 1/1998. University Presses of Yaoundé, 1, 3-11. 